\title{
IMPLEMENTASI MODEL E-COMMERCE UNTUK MENINGKATKAN PENJUALAN PAKAIAN MENGGUNAKAN CONTENT MANAGEMENT SYSTEM, SEARCH ENGINE OPTIMIZATION DAN STRATEGI MARKETING 4P
}

\author{
Agus Umar Hamdani ${ }^{1)}$, Aldy Himawan ${ }^{2)}$ \\ Sistem Informasi, Fakultas Teknologi Informasi, Universitas Budi Luhur \\ Jl. Raya Ciledug, Petukangan Utara, Kebayoran Lama, Jakarta Selatan 12260 \\ E-mail : agus.umarhamdani@ budiluhur.ac.id ${ }^{1)}, \underline{1412520114 @ \text { student.budiluhur.ac.id }^{2)}}$
}

\begin{abstract}
Abstrak
Persaingan bisnis yang semakin pesat saat ini mendorong pemilik usaha untuk mengembangkan bisnisnya dengan perantara teknologi informasi. Salah satu teknologi informasi yang digunakan untuk tujuan bisnis adalah perdangan elektronik atau dikenal dengan istilah E-Commerce. Toko XYZ adalah toko yang menjual berbagai jenis model pakaian pria dan wanita di Jakarta. Dalam keberlangsungnya masih memiliki beberapa permasalahan, pelanggan tidak mengetahui informasi produk/diskon terbaru, pemesanan dan pembayaran produk masih dilakukan manual dengan datang ke toko, tidak ada informasi stok produk dan kurangnya promosi. Kedepannya Toko XYZ berharap dapat bersaing dengan adanya Website Toko Online. Adapun metodologi yang digunakan dalam penelitian menggunakan metode Business Model Canvas untuk menganalisis model bisnis, analisis dan perancangan E-Commerce menggunakan pendekatan Object Oriented Analysis and Design dengan tools Unified Modeling Language, implementasi aplikasi E-Commerce menggunakan Content Management System (CMS), teknik Search Engine Optimization menggunakan pendekatan optimasi On-Page dan teknik pemasaran menggunakan strategi marketing 4P (Product, Promotion, Price dan Place). Dengan adanya toko online, maka pelanggan baru dapat dengan mudah melakukan pemesanan, serta mendapatkan informasi terkait produk-produk yangg ada di Toko XYZ.
\end{abstract}

\section{Kata kunci: E-Commerce, Pakaian, Content Management System, Search Engine Optimization, Strategi Marketing $4 P$}

\section{PENDAHULUAN}

Perkembangan teknologi informasi yang semakin maju saat ini memberikan manfaat bagi masyarakat, terutama dalam hal kemanfaatan dan efektifitas [1]. Teknologi informasi berperan penting dalam menunjang bisnis perusahaan dalam hal penyediaan alat yang dapat menghasilkan informasi yang berkaitan dengan bisnis perusahaan [2]. Contoh teknologi yang digunakan dalam bisnis teknologi E-Commerce. E-Commerce adalah proses pembelian, penjualan dan pemasaran barang, serta jasa melalui sistem elektronik, seperti radio, televisi dan jaringan komputer atau internet [3]. Teknologi informasi dapat membantu perusahaan dalam melakukan transaksi bisnis baik kepada pelanggan maupun kepada supplier. Toko XYZ adalah salah satu bisnis yang bergerak di bidang penjualan pakaian fashion untuk pria dan wanita dan beralamat di Tanah Abang, Jakarta Pusat. Kondisi yang terjadi pada Toko XYZ saat ini adalah belum tersedianya sistem yang menangani layanan penjualan secara terkomputerisasi, dimana semua layanan penjualan masih dilakukan secara manual. Pelanggan diminta datang ke toko untuk membeli kebutuhan yang diinginkan. Selain itu, penggunaan perangkat teknologi informasi untuk membantu layanan penjualan dirasakan masing sangat kurang sehingga menyebabkan beberapa masalah, antara lain : pelanggan tidak mengetahui informasi produk/diskon terbaru, pemesanan dan pembayaran produk masih dilakukan manual dengan datang ke toko, tidak ada informasi stok produk dan kurangnya promosi. Beberapa studi literatur terkait dengan penelitian yang dilakukan, antara lain antara lain : penelitian pertama [4] yang membahas implementasi E-Commerce sebagai media penjualan online pada Toko Pastbrik Kota Malang. Metode yang digunakan dalam penelitian tersebut adalah pendekatan deskriptif kualitatif. Penelitian kedua [5] membahas proses untuk meningkatkan penjualan souvenir pernikahan dengan memanfaatkan aplikasi E-Commerce. Penelitian tersebut mengunakan bahasa pemrograman PHP dalam rangka mengimplementasikan E-Commerce. Penelitian ketiga membahas perancangan sistem informasi penjualan online pada Tokoku [6]. Metodologi yang digunakan dalam penelitian tersebut adalah metode deskriptif. Berdasarkan kondisi yang terjadi di Toko XYZ dan merujuk pada beberapa studi literatur diatas, maka peneliti melakukan analisis dan kajian dalam rangka membuat model dan aplikasi ECommerce untuk membantu layanan penjualan secara online pada Toko XYZ. Rumusan masalah yang harus dijawab dalam penelitian ini adalah bagaimana membuat model E-Commerce untuk membantu meningkatkan penjualan pada Toko $\mathrm{XYZ}$ ? 


\section{METODOLOGI PENELITIAN}

Adapun kerangka kerja penelitian yang penulis lakukan dapat dilihat pada gambar 1 .

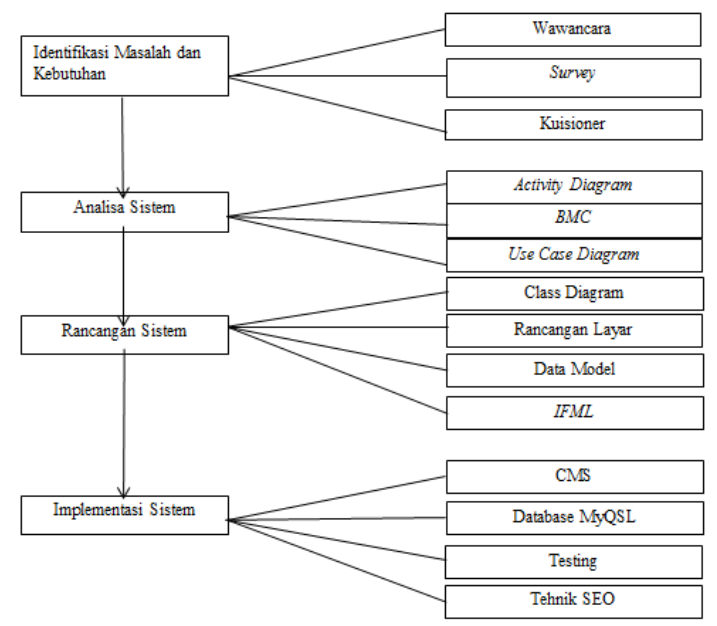

Gambar 1. Kerangka Kerja Penelitian

Tahapan penelitian diawali dengan mengidentifikasi masalah dan kebutuhan di Toko XYZ yang dilakukan dengan wawacara dan observasi. Tahap kedua adalah melakukan analisis bisnis pada sistem berjalan dengan membuat Business Model Canvas, untuk perancangan sistem menggunakan pendekatan Unified Modeling Language, yaitu Activity Diagram, Use Case Diagram dan Class Diagram. Business Model Canvas adalah adalah salah satu strategi yang digunakan untuk mendeskripsikan sebuah model bisnis dan menggambarkan bagaimana sebuah organisasi menciptakan, memberikan dan menangkap nilai bisnis [7]. Unified Modeling Language adalah bahasa pemodelan untuk sistem atau perangkat lunak yang berparadigma berorientasi obyek [8]. Tahap ketiga adalah melakukan perancangan sistem dengan membuat model Class Diagram, rancangan layar, System Sequence Diagram dan Interaction Flow Modeling Language. Interaction Flow Modeling Language (IFML) adalah bahasa pemodelan yang distandarissi oleh OMG (Object Management Group) untuk mewakili aplikasi Front-End secara independen dari teknologi atau perangkat target. Pada dasarnya, IFML merupakan sekumpulan elemen visual yang mewakili interaksi pengguna dan perilaku FrontEnd [9]. Tahap terakhir adalah implementasi sistem E-Commerce dengan instalasi Content Management System menggunakan Wordpress. Content Management System adalah perangkat lunak yang digunakan untuk menambahkan atau memanipulasi (mengubah) isi dari suatu situs web [10], penerapan teknis Search Engine Optimization. Search Engine Optimization merupakan sebuah proses yang menggunakan prinsip-prinsip dasar pencarian dari sebuah mesin pencari untuk mendapatkan dan meningkatkan nilai indeks peringkat yang lebih tinggi untuk sebuah halaman website atau juga dapat digunakan untuk meningkatkan jumlah akses pengunjung [11]. Serta implementasi strategi pemasaran menggunakan strategi marketing 4P (Product, Price, Place dan Promotion). Strategi Pemasaran (marketing mix) adalah strategi mengkombinasikan kegiatan-kegiatan marketing agar tercipta kombinasi maksimal sehingga akan muncul hasil paling memuaskan [12].

\section{HASIL DAN PEMBAHASAN}

\subsection{Business Model Canvas}

Berikut ini adalah hasil analisis Business Model Canvas (BMC) dengan 9 (Sembilan) komponen-komponen dalam Bussines Model Canvas ini yang dijelaskan sebagai berikut:

a. Value Proposition, Comet Merupakan nilai lebih yang diberikan Toko XYZ untuk para customer melalui produknya, yaitu harga terjangkau, banyak pilihan model, kualitas bahan bagus dan warna bahan tidak mudah pudar.

b. Customer Segments, Merupakan target pasar yang menjadi fokus Toko XYZ dalam menjualkan produknya. Target customer pada Toko XYZ contoh remaja dewasa dan orang kantor.

c. Customer Relationships Merupakan usaha Toko XYZ dalam menjalin hubungan dengan para customernya. Dengan cara mengadakan potongan harga (diskon).

d. Channels, Merupakan suatu metode XYZ dalam menawarkan produknya kepada para customer. Pada Toko XYZ adalah mengukti bazzar, menggunakan media sosial (Instagram dan Facebook) dalam mempromosikan produknya dan website (tidak terurus).

e. Key Activities Merupakan kegiatan-kegiatan penting yang dilakukan Toko XYZ untuk mendukung tercapainya suatu keberhasilan usaha. Melakukan survey untuk harga pemasaran dan melakukan packing produk.

f. Key Partners, Merupakan suatu kerja sama antara Toko XYZ dengan mitra. Toko Pakaian Al-Jabbar menjalin kerja sama dengan toko bahan, tukang jahit, kurir (JNE, JNT dan Wahana), dan bank.

g. Key Recources, Merupakan sumber daya yang diperlukan Toko XYZ dalam menunjang keberhasilannya. Adapun physical asset yang dimiliki oleh Toko XYZ adalah handphone, laptop, internet.

h. Cost Structure, Merupakan biaya yang dikeluarkan Toko XYZ dalam menjalankan usahanya. Antara lain membeli bahan baku, biaya proses produksi, biaya transportasi, biaya kemasan dan packing, dan biaya internet.

b. Revenue Segements, Merupakan pendapatan atau profit yang didapatkan oleh Toko XYZ dalam menjual produknya. Toko XYZ menghasilkan keuntungan dari asset sale, yaitu: menjual baju muslim dan kemeja kerja. 
Berdasarkan hasil analisis Business Model Canvas diatas, maka berikut ini adalah model Business Model Canvas pada Toko XYZ yang dijelaskan pada gambar 2.

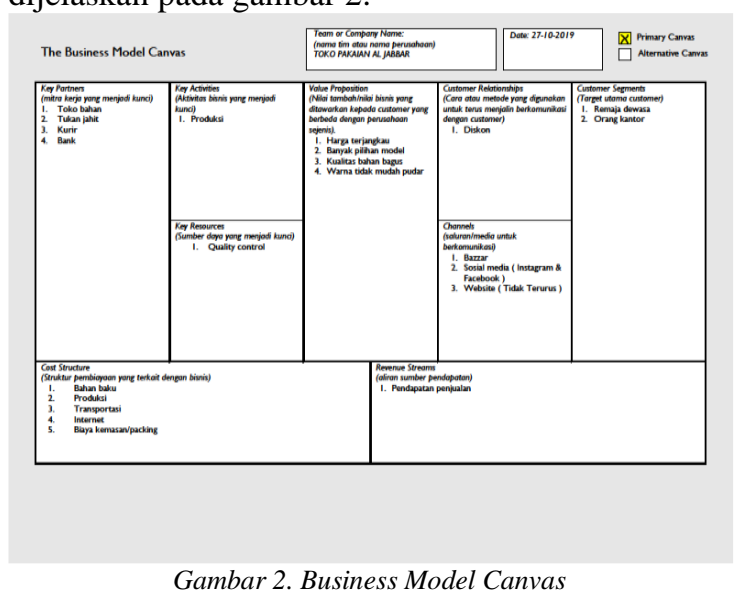

\subsection{Activity Diagram Pemesanan Produk}

Customer dapat memilih produk yang akan dibeli dengan memilih menu Select Options.dan masuk ke halaman Cart. Setelah itu, customer dapat menginput jumlah produk dan ukuran size-nya. Kemudian memilih menu View Cart dan Proceed to Checkout. Jika customer sudah punya akun login, maka system akan melanjutkan ke proses tagihan pembayaran. Jika customer belum memiliki akun login, maka sistem akan mengarahkan ke halaman registrasi login. Kemudian pesanan akan divalidasi oleh sistem dan system akan mengirimkan bukti invoice.

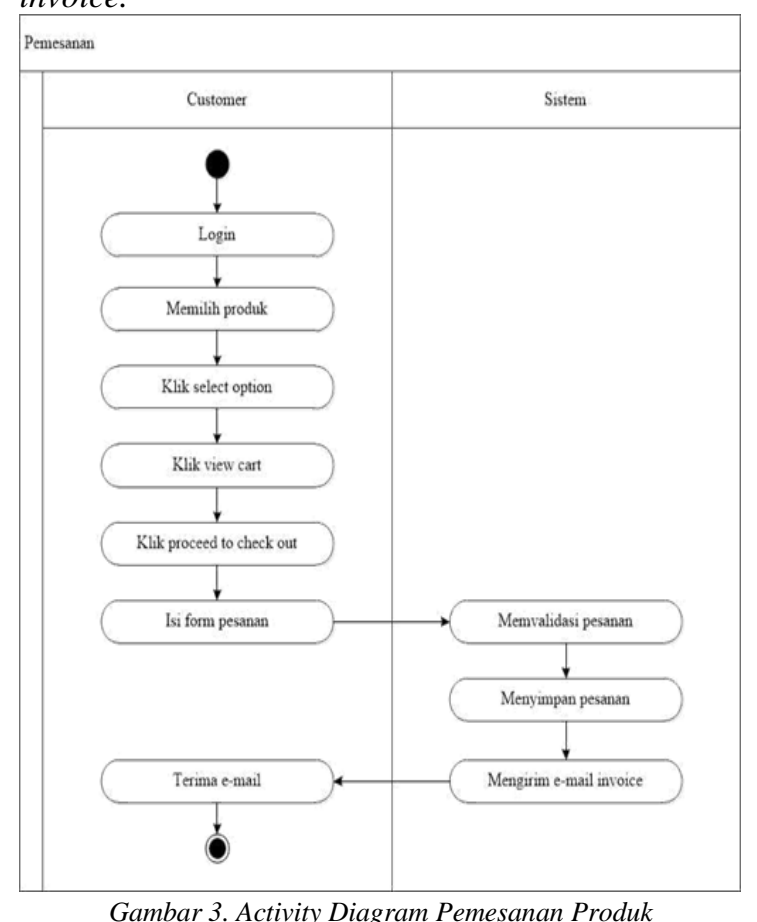

\subsection{Activity Diagram Konfirmasi Pembayaran}

Customer melakukan pembayaran ke bank terpilih dan sistem akan melakukan konfirmasi pembayaran ke admin dan mengirimkan bukti pembayaran ke email customer. Kemudian admin merubah status pesanan menjadi berstatus sudah dibayarkan.

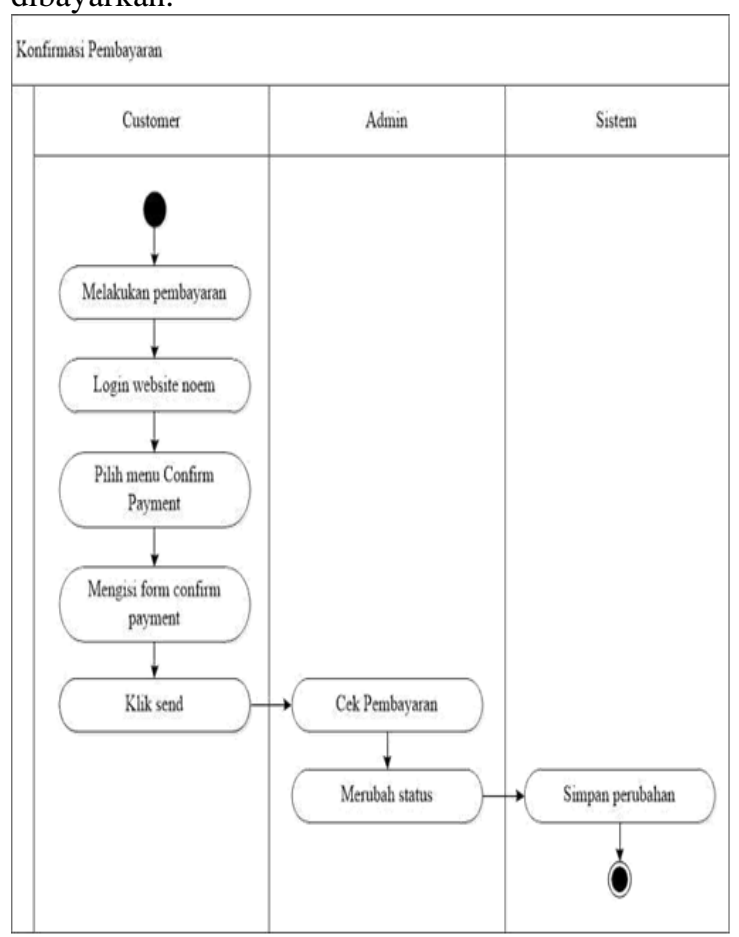

Gambar 4. Activity Diagram Konfirmasi Pembayaran

\subsection{Use Case Diagram}

Use case diagram digambarkan berdasarkan proses bisnis usulan, sebagai berikut:

a. Use Case Diagram Master

Pada gambar 5 merupakan use case diagram master yang terdiri dari dua actor, yaitu admin dan pelanggan. Admin dapat melakukan input entry product, entry kurir, entry coupon dan konfirmasi registrasi. Pelanggan data melakukan registrasi. Selengkapnya dapat digambarkan pada gambar 5.

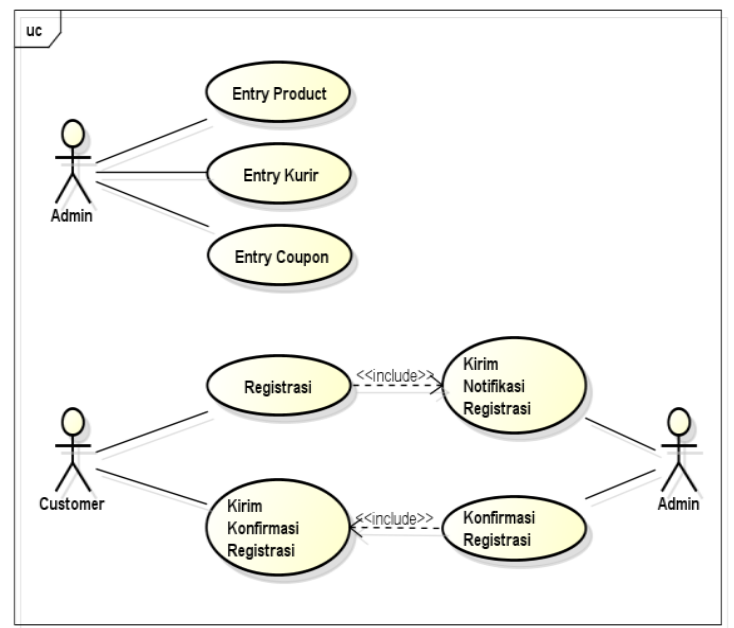

Gambar 5. Use Case Diagram Master

\section{b. Use Case Diagram Transaksi}

Pada gambar 6 merupakan use case diagram transaksi, admin yang terdapat input update status pesanan dan entry coupon dapat digambarkan pada gambar dibawah ini: 


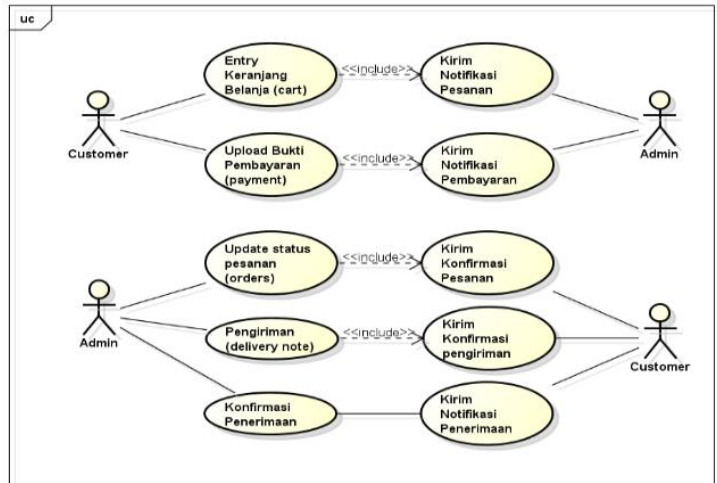

Gambar 6. Use Case Diagram Transaksi

\section{c. Use Case Diagram Laporan}

Pada gambar 7 merupakan use case diagram laporan yang terdiri dari: order report, top product report, summary report, shipping report, coupon report, dan stock report.

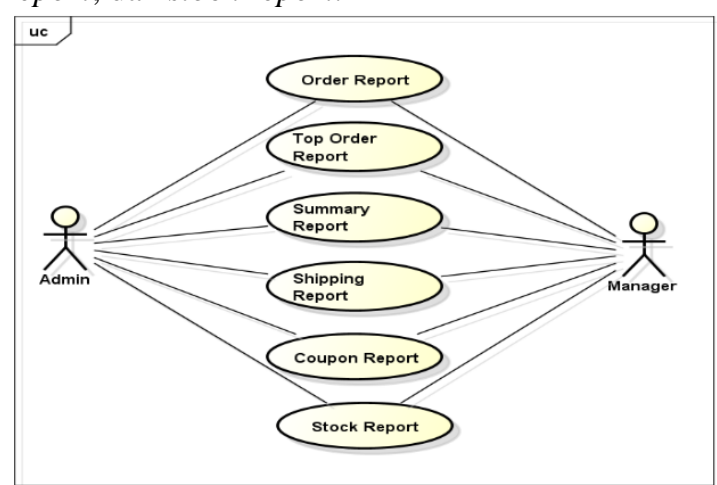

Gambar 7. Use Case Diagram Laporan

\subsection{Class Diagram}

Adapun model domain data pada sistem ECommerce ini dapat dilihat pada pada gambar 8 . Domain data yang terbentuk antara lain: wp_usermeta, wp-users, wp_comments, wp_terms, $w p \_p o s t, \quad \quad w p \_w c \_p r o d u c t \_m e t a \_l o o k u p$, wp_postmeta, wp_coocommerce_order_itemmeta dan wp_woocommerce_order_item.

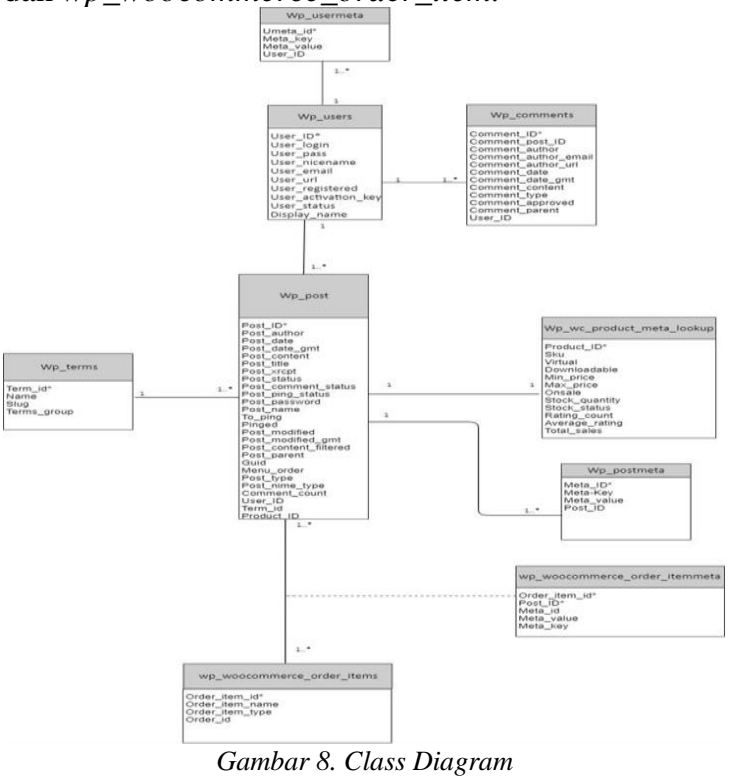

\subsection{System Sequence Diagram Pemesanan Barang}

Pada gambar 9 merupakan System Sequence Diagram pemesanan barang.

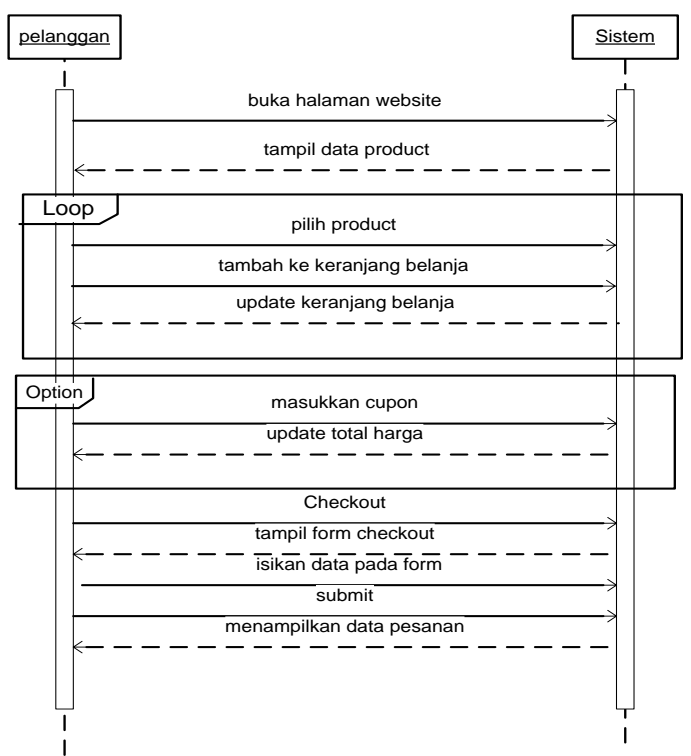

Gambar 9. Sistem Sequance Diagram Entry Pemesanan Barang (cart)

\subsection{Implementasi Sistem}

a. Halaman Home

Pada gambar 10 merupakan tampilan awal website Toko Pakaian Al-Jabbar .

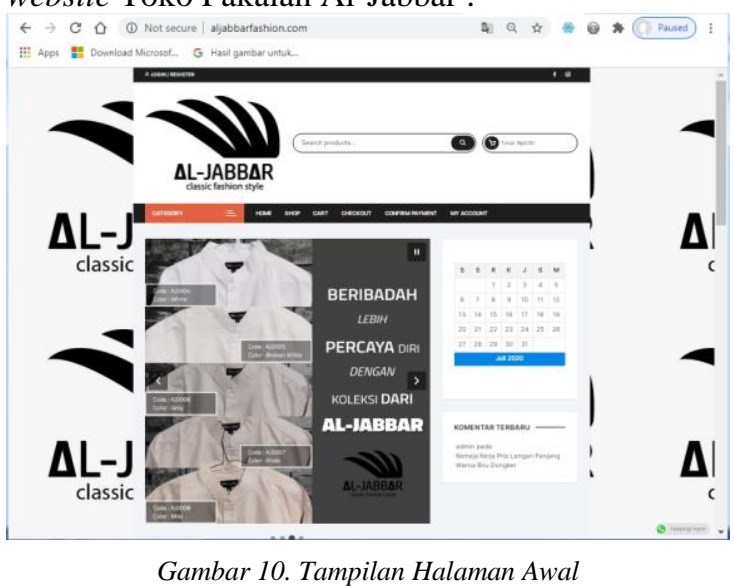

b. Tampilan Halaman Keranjang Belanja

Pada gambar 11 merupakan tampilan halaman Keranjang Belanja dan halaman Checkout pada aplikasi E-Commerce pada Toko XYZ.

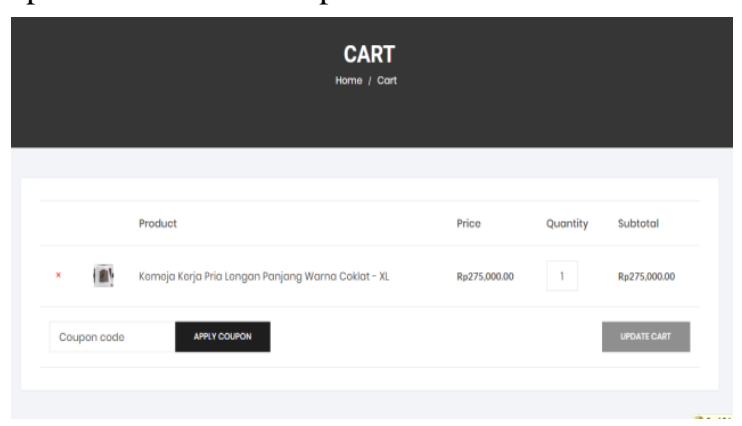




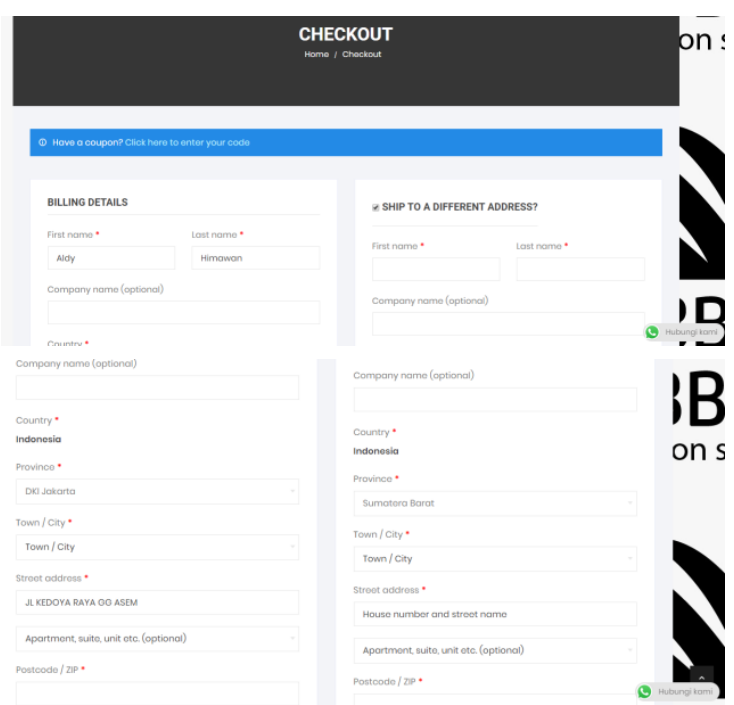

Gambar 11. Tampilan Halaman Keranjang Belanja (Cart)

c. Tampilan Konfirmasi Pembayaran (Payment)

Pada gambar 12 merupakan tampilan halaman konfirmasi pembayaran (Payment) pada website ECommerce pada Toko XYZ.

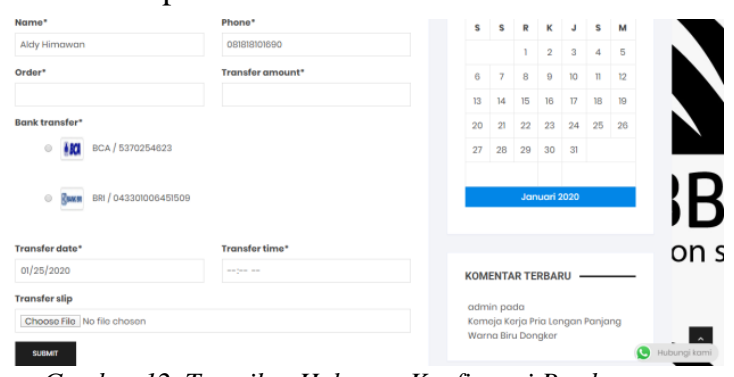

Gambar 12. Tampilan Halaman Konfirmasi Pembayaran (Confirm Payment)

\subsection{Hasil Keluaran Program}

Berikut ini adalah hasil keluaran dari aplikasi E-Commerce pada Toko XYZ ialah sebagai berikut: a. Laporan Order Produk

Pada gambar 13 merupakan hasil dari keluaran laporan order produk ialah sebagai berikut:

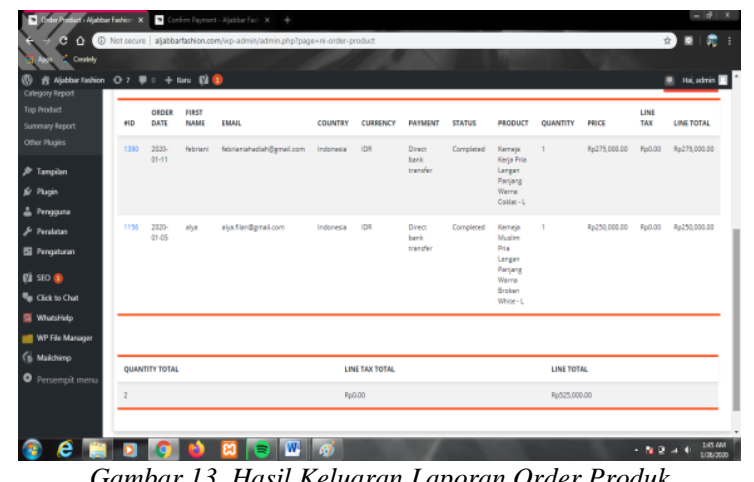

Gambar 13. Hasil Keluaran Laporan Order Produk

b. Email Notifikasi Pesanan

Pada gambar 14 merupakan hasil dari keluaran bukti pesan yang diterima oleh pelanggan melalui email sebagai berikut:

\section{New Order: \#1390}

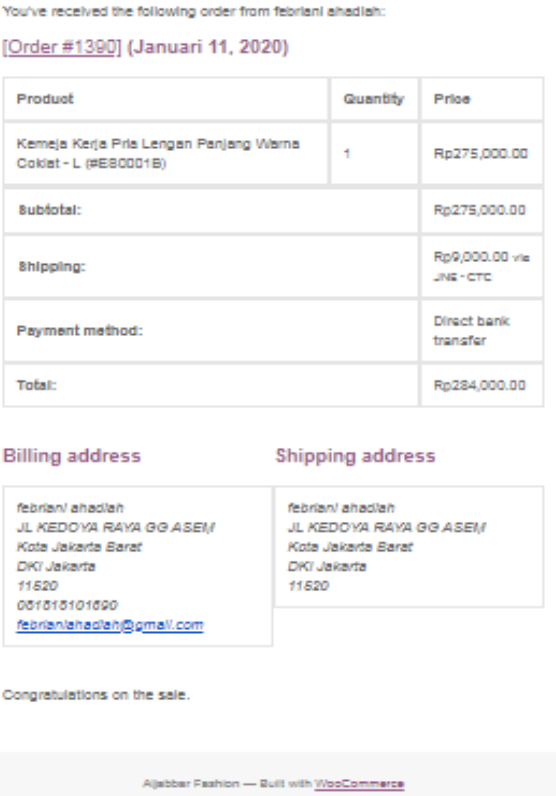

Gambar 14. Email Notifikasi Butki Pesan Melalui Email

\subsection{Implementasi Search Engine Optimization (SEO)}

Berikut ini implementasi SEO pada aplikasi ECommerce menggunakan plugin Yoast SEO:

1. Tentukan Target Keyword:

a. Kemeja Kerja Pria

Kemeja Kerja, Kemeja Pria, Kemeja, Kerja, Pria, kemeja lengan Panjang, kemeja pria lengan panjang

b. Kemeja Muslim Pria

Kemeja Muslim, Muslim Pria, Kemeja, Muslim, Pria

2. Tentukan Tags Yang digunakan :

Kemeja Kerja, Kemeja Pria, Kemeja, Kerja, Pria, kemeja lengan Panjang, kemeja pria lengan Panjang, Kemeja Muslim Pria, Kemeja Muslim, Muslim Pria, Kemeja, Muslim, Pria

3. Memasukan kata kunci pada deskripsi.

Kemeja Kerja, Kemeja Pria, Kemeja, Kerja, Pria, kemeja lengan Panjang, kemeja pria lengan Panjang, Kemeja Muslim Pria, Kemeja Muslim, Muslim Pria, Kemeja, Muslim, Pria

\subsection{Hasil Search Engine Optimization}

Hasil dari implementasi strategi Search Engine Opimization yang telah penulis terapkan dan berada dihalaman pertama posisi 3 dengan keyword "kemeja muslim pria Kampung Bali" yang selengkapnya dapat dilihat pada gambar 15 . 


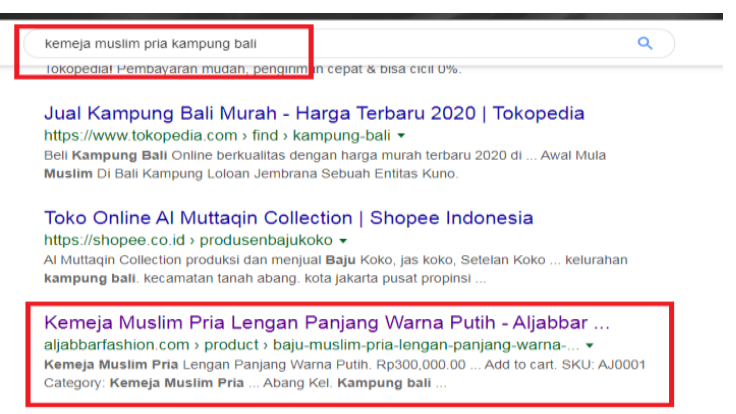

Gambar 15. Hasil Implementasi Strategi SEO

\subsection{Strategi Pemasaran (Marketing)}

Strategi Marketing yang diusulkan oleh penulis untuk Toko XYZ dalam meningkatkan penjualan menggunakan pendekatan 4P (Product, Price, Place dan Promotion). Dari keempat komponen tersebut, hanya komponen Price dan Promotion yang digunakan dalam penelitian ini. Tabel 1 merupakan strategi pemasaran yang diusulkan oleh peneliti.

Tabel 1. Implementasi Strategi Pemasaran 4P

\begin{tabular}{|c|c|}
\hline $\begin{array}{c}\text { Komponen Strategi } \\
\text { Pemasaran 4P }\end{array}$ & Strategi yang dilakukan \\
\hline $\begin{array}{l}\begin{array}{l}\text { Price } \\
\text { (strategi harga) }\end{array} \\
\end{array}$ & $\begin{array}{l}\text { - Pemberian diskon kepada } \\
\text { pelanggan lama. }\end{array}$ \\
\hline $\begin{array}{l}\text { Promotion } \\
\text { (Strategi promosi) }\end{array}$ & $\begin{array}{l}\text { Membuat postingan promosi } \\
\text { produk pada facebook pada jam } \\
\text { dimana media sosial banyak } \\
\text { digunakan misalnya: } \\
\text { - Pukul } 05.00 \text { s.d } 06.00 \\
\text { adalah waktu potensial. } \\
\text { Karena saat itu orang-orang } \\
\text { belum terlalu sibuk dengan } \\
\text { aktivitas pribadi. } \\
\text { - Pukul } 11.00-12.00 \text { adalah } \\
\text { waktu orang-orang istirahat } \\
\text { dari kesibukan mereka. } \\
\text { Pukul 17.00 s.d 22.00, } \\
\text { malam hari adalah waktu } \\
\text { paling leluasa untuk } \\
\text { seseorang menggunakan } \\
\text { gadget mereka lebih sering. } \\
\text { Tidak cantumkan harga pada } \\
\text { postingan postingan, hal ini } \\
\text { diharapkan agar customer } \\
\text { langsung mengakses website } \\
\text { toko online. }\end{array}$ \\
\hline
\end{tabular}

Gambar 16 merupakan contoh implementasi strategi promosi menggunakan fitur posting di Facebook.

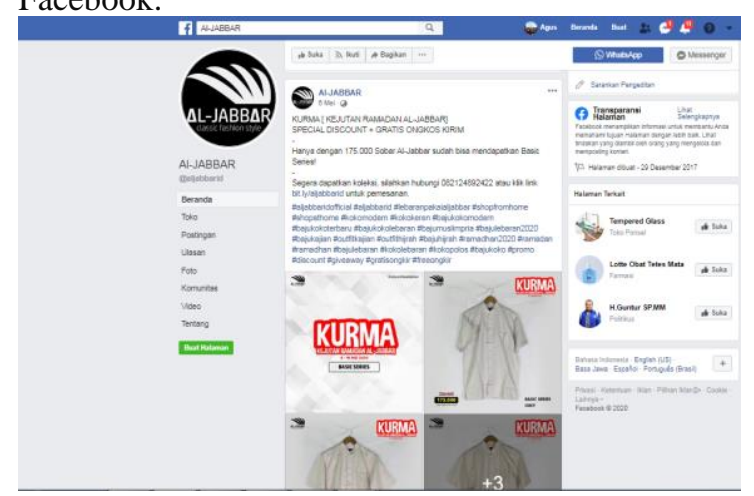

Gambar 16. Strategi Promosi via Facebook
Gambar 17 merupakan contoh implementasi strategi diskon (price) di halaman katalog produk.

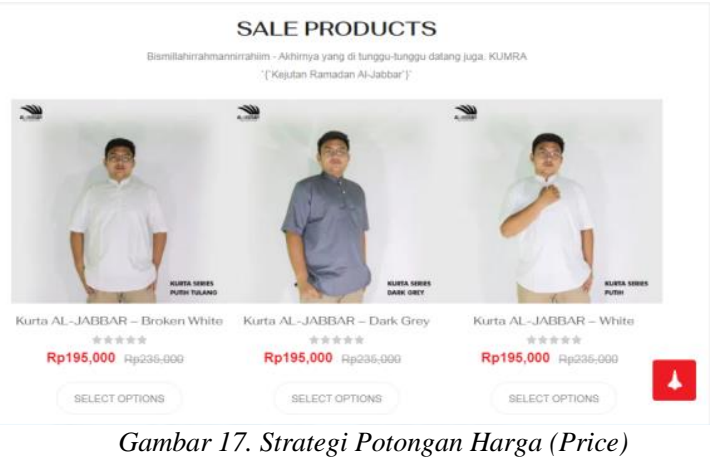

\section{KESIMPULAN}

Berdasarkan hasil analisis, perancangan dan implementasi model E-Commerce pada Toko XYZ, maka dapat ditarik kesimpulan sebagai berikut:

a. Dengan adanya fitur order report dan summary report, maka manajer toko bisa melakukan rekap transaksi pengeluaran dan masukan secara terperinci, lebih akurat, efektif dan efisien.

b. Dengan adanya fitur konfirmasi pembayaran (Confirm Payment), maka pelanggan bisa melakukan pembayaran melalui transfer tanpa harus datang ke toko.

c. Dengan adanya fitur strategi potongan harga (price) dan strategi pemesaran via facebook (promotion), maka produk dapat dikenali sehingga dapat menarik pelanggan untuk melakukan pemesanan produk.

d. Dengan fitur notifikasi pesanan yang dikirim via email, maka nota manual sudah tidak lagi dipakai, karena bukti nota sudah dikirim otomatis melalu email.

e. Dengan fitur stock report, maka dapat memberikan kemudahan kepada manager toko mengelola data ketersediaan produk.

\section{DAFTAR PUSTAKA}

[1] T. Wyne W, Chin \& Peter A, "On The Use, Usefulness, and Ease Of Use A Structural Equation Modeling in MIS Research : A Note of Caustion" MIS Q., 1995.

[2] S. U. Setyaningsih, "Pengaruh Teknologi Informasi Dalam Perkembangan Bisnis.," J. Akuntansi dan Sistem Teknologi Informasi, vol. 8(1), pp. 61-67, 2010.

[3] W. Jony, Internet Marketing for Beginner. Jakarta: Elex Media Komputindo, 2010.

[4] S. and R. Miftah Shabur, Maulana., Heru, "Implementasi E-Commerce Sebagai Media Penjualan Online (Studi Kasus Pada Toko Pastbrik Kota Malang)," Jurnal Administrasi Bisnis, vol. 29(1), 2015.

[5] E. H. \& Ismiyatih, "Aplikasi E-Commerce Penjualan Souvenir Pernikahan Pada Toko XYZ," Jurnal PROSISKO, vol. 4(1), pp. 6347, 2017. 
[6] F. Eko Nugroho, "Perancangan Sistem Informasi Penjualan Online Studi Kasus Tokoku," J. Simetris, vol. 7(2), 2016.

[7] O. and Y. P. Alexander, Business Model Generation. Jakarta: Elex Media Komputindo, 2012.

[8] Nugroho Adi, Rekayasa Perangkat Lunak Berbasis Objek Dengan Metode USDP. Yogyakarta: Andi Press, 2010.

[9] P. Brambilla, M \& Fraternali, Interaction Flow Modeling Language: Model-Driven UI Engineering of Web and Mobile Apps with IFML. Amsterdam: Elsevier Science, 2014.

[10] S. Rockley, Ann., Kostur, Pamela \& Manning, Managing Enterprise Content: A Unified Content Strategy. New Riders, 2003.

[11] W. A. T. \& S. N, "Optimasi Meta Tag HTML untuk meningkatkan Search Engine Optimization pada Website E-Commerce UMKM," Journal Network Security, vol. 6(4), pp. 1-5, 2017.

[12] A. Buchari, Manajemen Pemasaran dan Pemasaran Jasa, Cetakan 5. Bandung: Alfabeta, 2005. 